\title{
Testing Multi-Factor Models in ADRs: Emerging Market vs. Developed Market
}

\author{
Tingting Que $P h D$ \\ Assistant Professor \\ College of Business \\ University of Alabama in Huntsville \\ 30I Sparkman Dr NW \\ Huntsville, AL 35899, USA \\ E-mail: tingting.que@uah.edu \\ Wai Yin Mok $P h D$ \\ Professor \\ College of Business \\ University of Alabama in Huntsville \\ 30I Sparkman Dr NW \\ Huntsville, AL 35899, USA \\ E-mail:mokw@uah.edu \\ Kit Yee Cheung \\ College of Business \\ University of Alabama in Huntsville \\ 30I Sparkman Dr NW \\ Huntsville, AL 35899, USA \\ E-mail: kityeemok@gmail.com
}

\begin{abstract}
This paper tests whether the Carhart four-factor model and the Fama-French five-factor model can explain variation in returns of I,230 ADRs originating from six developed markets and five emerging markets. We aim to compare emerging market ADRs with developed market ADRs in terms of traditional risk factors significance, model fitness and the existence of abnormal returns. Overall, we find that substantial variations exist among ADRs by their origin-of-market. First, both models show that most of the positive abnormal returns we document accrue to emerging market ADRs, mainly Chinese ADRs. Among the risk factors, market risk premium is found to be most prevalent in both emerging and developed markets. Although we find some difference in the presence of particular risk factors employed in the four-factor vs. five-factor model, overall, there are no significant differences in the explanation power between the two models. Lastly, the low $R^{2}$ values imply that both models do not work very well with the international market ADRs.
\end{abstract}

Keywords: Carhart Four-Factor Model, Fama-French Five-Factor Model, ADRs, Developed Markets, Emerging Markets.

\section{Introduction}

American Depositary Receipts (ADRs) are negotiable instruments that represent shares of non-U.S. companies that are held by a U.S. depositary bank outside the United States. Since JPMorgan established the first depositary receipt program in I927, the ADR markets have gained momentum since the beginning of 2000 and continued to accelerate in growth after the 2007 meltdown. As one example of the fastest growing groups of ADRs, Chinese ADRs have experienced explosive growth in the ADR markets, totaling 323 as of June 2019 compared to less than 100 before 2009 (Morningstar). Globalization has created an entirely new platform for companies to look beyond their home borders to increase their international footprints, expand their investor base and raise capital. There are more than 2000 ADRs, representing companies located in more than 70 countries. ADRs account for I6\% of the entire U.S. equity markets (JP Morgan, 2006).

As investing in ADRs has become an attractive investment opportunity to diversify one's portfolio without the high costs of international transactions and to take advantage of potential growth in foreign markets, especially in emerging markets, investors and academic researchers alike try to understand the equity returns of ADRs in order to seek optimal investment strategies. As a result, numerous studies have examined ADR returns (Alhaj-Yaseen et al., 2019 ; Blau, 2017 ; Boubakri et al., 
2010 ; Foye, 2018 ; Griffin , 2002 ; Hail \& Leuz, 2009 ; Kadiyala \& Subrahmanyam , 2004 ; Karolyi , 2006). Given the growing interest in ADRs market, we aim to evaluate whether the traditional factor models can generalize to the ADRs. Specifically, we select the Carhart four-factor model (4FM) and the Fama-French five-factor model (5FM), both of which are the major workhorse models in this area. We further compare emerging market ADRs with developed market ADRs in terms of traditional risk factors significance, model fitness and the existence of abnormal returns. Lastly, by comparing the 4FM with the 5FM, we can show whether the 5FM can better explain the variation in return of ADRs than the 4FM.

The I,230 ADRs in our sample originate from eleven international markets. The six developed markets include Australia, France, Germany, Hong Kong, Japan, and UK from various continents around the worldi. The five emerging markets are Brazil, Russia, India, China, and South Africa, known as BRICS, representing about $40 \%$ of the world population.

To ensure consistent economic factors throughout the study period, we set our sample period to be from June 2009 to July 2019, which marks the longest expansion period of a business cycle of the post-World War II era after the last contraction from December 2007 to June 2009 according to the National Bureau of Economic Research.

We start by using the ordinary least squares (OLS) model with fixed-effects as the baseline model to estimate the 4FM and the 5FM in the whole sample of ADRs. None of the risk factors is significant in either of the two models. But the Alpha of 4FM, measured by the excessive return above the expected return due to market, size, value, momentum risk factors, is positive and significant, suggesting existence of abnormal returns in the ADRs.

Next, we split the sample into developed markets ADRs vs. emerging markets ADRs, and explore whether there is significant difference between the two groups. Results show that none of the 5FM risk factors is significant in either market. However, the Alpha of 5FM, measured by the excessive return above the expected return due to market, size, value, profitability and investment risk factor, is found to be positive and significant in the emerging market ADRs, but insignificant in the developed market ADRs. Combined with the previous results, the abnormal returns we documented before accrue mostly to the emerging market ADRs, and there is scant evidence that abnormal return exist in the developed market ADRs. Estimation with the 4FM are similar, except that market risk effect is present in the emerging market ADRs, but not in the developed market ADRs.

Furthermore, we break down ADRs by market-of-origin and examined whether there exists difference among the markets-of-origin. Overall, our results show that substantial variations exist among ADRs originating from the eleven markets. Firstly, both the 5FM and 4FM show that most of the abnormal returns we document previously actually accrue to Chinese ADRs. Both models work the best in Hong Kong with most of risk factors highly significant. Among the risk factors, market risk premium is found to be most prevalent: present in four emerging markets and three developed markets in the 5FM, and in all five emerging markets and the same three developed markets in the 4FM, respectively. We also find presence of other risk factors in some of the individual markets.

This paper, to the best of the authors' knowledge, is the first study of testing both the 4FM and the 5FM using a comprehensive sample consisting of I,230 ADRs originating from eleven international markets. Also, this paper is the first to compare emerging market ADRs with developed market ADRs and provide strong evidence that substantial variations exist between them, especially that abnormal return exists in emerging market ADRs, mainly Chinese ADRs. Our study has the potential to shed light on the changing landscape of ADRs.

The rest of the paper proceeds as follows. Section 2 reviews the literature on the 4FM and 5FM. Section 3 presents the data source. Section 4 reports the empirical results and Section 5 concludes.

\section{Literature Review}

In this section we briefly review the literature on the Carhart four-factor model and Fama and French five-factor model.

\section{I Carhart Four-Factor Model (4FM)}

Carhart four-factor model is an extension of the (Fama \& French, 1998) three-factor model (3FM). The (Fama \& French, 2015) 3-factor model (Fama \& French, I992; Fama \& French, I993) is an asset pricing model developed in I992 that expands on the capital asset pricing model (CAPM) by adding size risk and value risk factors to the market risk factor in CAPM. This model considers the fact that value and small-cap stocks outperform markets on a regular basis. Although the 3FM already mitigates average CAPM pricing errors, it is unable to explain the cross-sectional variation in momentum-sorted portfolio returns. Therefore, Carhart (1997) extends the 3FM by adding a fourth factor that captures the (Jegadeesh \& Titman, I993) momentum anomaly. The resulting model is consistent with a market equilibrium model with four risk factors.

Formally, the model can be estimated as:

$$
R_{i t}-R_{f t}=\alpha_{i t}+\beta_{1}\left(R_{M t}-R_{f t}\right)+\beta_{2} S M B_{t}+\beta_{3} H M L_{t}+\beta_{4} W M L_{t}+\varepsilon_{i t}
$$


Where $R_{i t}$ is the total return of a stock i at time t; $R_{f t}$ is the risk free rate of return at time t; $R_{M t}$ is the total market portfolio return at time t; $R_{i t}-R_{f t}$ is expected excess return; $R_{M t}-R_{f t}$ is the excess return on the market portfolio (index); $S M B_{t}$ is the size premium (small minus big), that argues that small-cap companies should outperform the big-cap companies. $H M L_{t}$ is the value premium (high minus low), that argues that companies with high book-to-market ratios outperform those with lower book-to-market values. $W M L_{t}$ is the difference in return between a portfolio of past 12 month winners and a portfolio of past 12 month losers at time t. $\beta_{1,2,3,4}$ refer to the factor coefficients. $\varepsilon_{i t}$ is the residual. The Alpha of $4 \mathrm{FM}\left(\alpha_{i t}\right)$ denotes the excessive return above the expected return due to market, size, value, momentum risk factors.

Hong et al. (2000); Jegadeesh (1990); Nijman et al. (2004) all examined momentum returns of firm size and value. Jegadeesh (1990) investigates the New York Stock Exchange (NYSE) and find that stocks that have performed well over the past few months tend to earn high returns over the next months, while stocks that have performed poorly over the past few months tend to earn low returns over the next months. Hong et al. (2000) find that portfolio of stocks with the highest market value does not exhibit momentum effect. Nijman et al. (2004) studies the momentum effect on the basis of size and value in the European stock market and find that momentum effect is more pronounced for small growth stocks.

\subsection{Fama and French Five-Factor Model (5FM)}

In a more recent study, (Fama \& French, 2015) introduces a five-factor model by augmenting the 3FM with two mimicking factors that capture the return premiums associated with profitability and investment. This change is motivated by the valuation theory and by recent empirical findings concerning the strong effects of profitability and investment on asset returns. Fama \& French (2015) find that the five-factor model outperforms the 3FM in explaining the cross section of stock returns. Fama \& French (2015) extended their three-factor model based on dividend discount model as follows:

$$
R_{i t}-R_{f t}=\alpha_{i t}+\beta_{1}\left(R_{M t}-R_{f t}\right)+\beta_{2} S M B_{t}+\beta_{3} H M L_{t}+\beta_{4} R M W_{t}+\beta_{4} C M A_{t}+\varepsilon_{i t}
$$

Where $R M W_{t}$ is the robust-minus-weak profitability factor computed by constructing the size and operating profitability-ranked benchmark portfolios. $C M A_{t}$ is the conservative-minus-aggressive investment factor computed by constructing size and INV-ranked benchmark portfolios. The Alpha of 5FM $\left(\alpha_{i t}\right)$ denotes the excessive return above the expected return due to market, size, value, profitability and investment risk factors.

Strikingly, (Fama \& French, 2015) conclude that the book-to-market factor becomes redundant in the presence of the profitability and investment factors. In line with this argument, (Hou et al., 2015) strongly advocate a four-factor model that includes the market and the mimicking factors of size, profitability, and investment and suggest that it can serve as a new workhorse model in the area.

\section{Data}

The list of ADRs from the eleven chosen countries are extracted from Morningstar and the ADRs' historical price data between 6/I/2009 and 7/3I/2019 are extracted from Yahoo Finance by using the Python package "yfinance." Yahoo Finance was chosen as the data source because "yfinance" allows us to conveniently connect to and download data from the Yahoo's servers. The Fama and French factors and Carhart's momentum factor are obtained from Kenneth R. French's data library"i. The website provides data for specific regions around the world. For Fama and French factors, we use the Asia Pacific (excluding Japan) data for Hong Kong and Australia, Japanese data for Japan, European data for France, Germany, and UK, and emerging markets data for Brazil, China, India, Russia and South Africa. The momentum factors are analogously matched with the eleven international markets. Table I reports the number of ADRs originated from each of the eleven international markets.

Table I. Number of ADRs by origin-of-market

\begin{tabular}{lc}
\hline Market & Number of ADRs extracted \\
\hline Brazil & 68 \\
\hline China & 266 \\
\hline India & 13 \\
\hline Russia & 19 \\
\hline South Africa & 48 \\
\hline Australia & 105 \\
\hline France & 85 \\
\hline Germany & 94 \\
\hline Hong Kong & 69
\end{tabular}




\begin{tabular}{|c|c|}
\hline Japan & 284 \\
\hline UK & I79 \\
\hline Total & 1230 \\
\hline
\end{tabular}

Note. This table reports the number of ADRs originated from each of the eleven international markets. The six developed markets include Australia, France, Germany, Hong Kong, Japan, and UK. The five emerging markets are Brazil, China, India, Russia, and South Africa. ADR data is extracted from Yahoo Finance. The sample period is between 6/I/2009 and $7 / 31 / 2019$.

\section{Results}

\section{I Baseline Results}

In this section, we use the ordinary least squares (OLS) model with fixed-effects as the baseline model to estimate the 5FM and 4FM in the whole sample of ADRs originating from eleven international markets between June 2009 and July 2019.

The results are reported in Table 2. In model I, we estimate the 5FM (Equation I) using all observations. None of the five risk factors is significant at any conventional level. Then we turn to model 2 and estimate the 4FM (Equation 2). Consistent with model I, none of the four risk factors is statistically significant. But the Alpha of 4FM, measured by the excessive return above the expected return due to market, size, value, momentum risk factors is positive and significant at I $0 \%$ level, the coefficient is I25.48 with a $t$-statistics of I.65. The result suggests existence of abnormal returns in these international ADRs during our sample period. Furthermore, the $R^{2}$ value is 0.009 for both the 5FM and 4FM. There is no difference between the two models, which implies both models may have a similar explanation power on the risk and return pattern of ADRs.

Table 2. Baseline Model

\begin{tabular}{|c|c|c|}
\hline & Fama-French five-factor & Carhart four-factor \\
\hline & $(\mathrm{I})$ & $(2)$ \\
\hline \multirow[t]{2}{*}{ Alpha } & $\mathrm{I} 24.278$ & $\mathrm{I} 25.484^{\text {t }}$ \\
\hline & $(\mathrm{I} .56)$ & $(\mathrm{I} .65)$ \\
\hline \multirow[t]{2}{*}{$R_{M t}-R_{f t}$} & 10.126 & 10.965 \\
\hline & $(0.52)$ & $(0.60)$ \\
\hline \multirow[t]{2}{*}{$S M B$} & 44.368 & 32.789 \\
\hline & $(1.00)$ & $(0.78)$ \\
\hline \multirow[t]{2}{*}{$H M L$} & 66.692 & 58.955 \\
\hline & $(\mathrm{I} .26)$ & $(\mathrm{I} .5 \mathrm{I})$ \\
\hline \multirow[t]{2}{*}{$R M W$} & 44.089 & \\
\hline & $(0.59)$ & \\
\hline \multirow[t]{2}{*}{$C M A$} & -0.349 & \\
\hline & $(-0.0 \mathrm{I})$ & \\
\hline \multirow[t]{2}{*}{$W M L$} & & 25.182 \\
\hline & & $(0.89)$ \\
\hline Observations & 103,667 & 103,667 \\
\hline$R^{2}$ & 0.009 & 0.009 \\
\hline Fixed effects & $\mathrm{F}, \mathrm{T}$ & $\mathrm{F}, \mathrm{T}$ \\
\hline
\end{tabular}

Note. The table reports the results of OLS estimation with fixed effects of Fama-French five-factor model (Model I) and Carhart four-factor model (Model 2), where the dependent variable is the excess return of ADRs in eleven international markets between June 2009 and July 2019. Alpha of 5FM denotes the excessive return above the expected return due to market, size, value, profitability and investment risk factors. Alpha of $4 \mathrm{FM}$ denotes the excessive return above the expected return due to market, size, value, momentum risk factors. $R_{M t}-R_{f t}$ is the excess return on the market portfolio (index). $S M B$ is the size premium (small minus big). $H M L$ is the value premium (high minus low). $R M W$ is the robust-minus-weak profitability factor computed by constructing the size and operating profitability-ranked benchmark portfolios. CMA is the conservative-minusaggressive investment factor computed by constructing size and INV-ranked benchmark portfolios. WML is the premium on 
winners minus losers of past $\mathrm{I} 2$ months. $t$-statistics are given in parentheses. $\mathrm{F}, \mathrm{T}$ denotes firm and time fixed effects, and the symbols , and denote significance at the $1 \%, 5 \%$ and $10 \%$ levels, respectively.

\subsection{Estimation of 5FM and 4FM in Developed vs. Emerging Market ADRs}

In our sample, the eleven international markets that the ADRs originate from can be categorized into two major groups: developed markets and emerging markets. The six developed markets include Australia, France, Germany, Hong Kong, Japan and UK, and the five emerging markets include Brazil, China, India, Russia and South Africa. In this section, we explore whether there is significant difference between developed markets ADRs and emerging markets ADRs

Table 3. Estimation of Fama-French five-factor model in developed vs. emerging market ADRs

\begin{tabular}{|c|c|c|c|}
\hline & Developed market ADRs & Emerging market ADRs & All \\
\hline & $(\mathrm{I})$ & $(2)$ & (3) \\
\hline \multirow[t]{2}{*}{ Alpha } & I I0.386 & I46.116 & I26.868 \\
\hline & $(0.97)$ & $(2.75)$ & $(1.58)$ \\
\hline \multirow[t]{2}{*}{$R_{M t}-R_{f t}$} & 8.129 & I7.794 & II.055 \\
\hline & $(0.29)$ & (I.19) & $(0.28)$ \\
\hline \multirow[t]{2}{*}{$\left(R_{M t}-R_{f t}\right) \times$ Developed } & & & -3.005 \\
\hline & & & $(-0.07)$ \\
\hline \multirow[t]{2}{*}{$S M B$} & 62.545 & 1.276 & -12.175 \\
\hline & $(\mathrm{I} .04)$ & $(0.04)$ & $(-0.12)$ \\
\hline \multirow[t]{2}{*}{$S M B \times$ Developed } & & & 73.824 \\
\hline & & & $(0.68)$ \\
\hline \multirow[t]{2}{*}{$H M L$} & 77.272 & 30.3 II & 25.297 \\
\hline & $(1.09)$ & $(0.69)$ & $(0.2 \mathrm{I})$ \\
\hline \multirow[t]{2}{*}{$H M L \times$ Developed } & & & 53.624 \\
\hline & & & $(0.4 \mathrm{I})$ \\
\hline \multirow[t]{2}{*}{$R M W$} & 58.308 & 46.459 & 7.539 \\
\hline & $(0.58)$ & $(0.75)$ & $(0.05)$ \\
\hline \multirow[t]{2}{*}{$R M W \times$ Developed } & & & 51.870 \\
\hline & & & $(0.28)$ \\
\hline \multirow[t]{2}{*}{$C M A$} & 13.046 & -17.462 & $-\mathrm{II} .477$ \\
\hline & $(0.14)$ & $(-0.33)$ & $(-0.08)$ \\
\hline \multirow[t]{2}{*}{ CMA $\times$ Developed } & & & 23.656 \\
\hline & & & $(0.15)$ \\
\hline Observations & 69,738 & 33,929 & 103,667 \\
\hline$R^{2}$ & 0.008 & 0.029 & 0.009 \\
\hline Fixed effects & $\mathrm{F}, \mathrm{T}$ & $\mathrm{F}, \mathrm{T}$ & $\mathrm{F}, \mathrm{T}$ \\
\hline
\end{tabular}

Note. The table reports the results of OLS estimation with fixed effects of Fama-French five-factor model in developed vs. emerging market ADRs, respectively. The six developed markets (Model I) are Australia, France, Germany, Hong Kong, Japan and UK, and the five emerging markets (Model 2): Brazil, China, India, Russia and South Africa. The dependent variable is the excess return of ADRs between 2009 and 2019. Alpha of 5FM denotes the excessive return above the expected return due to market, size, value, profitability and investment risk factor. $R_{M t}-R_{f t}$ is the excess return on the market portfolio (index). Developed is an indicator variable that equals one if the ADR represents shares of the company that locates in a developed market, and zero otherwise. $S M B$ is the size premium (small minus big). $H M L$ is the value premium (high minus low). $R M W$ is the robust-minus-weak profitability factor computed by constructing the size and operating profitability-ranked benchmark portfolios. $C M A$ is the conservative-minus-aggressive investment factor computed by constructing size and INV-ranked benchmark portfolios. F, T denotes firm and time fixed effects, and the symbols , and denote significance at the I\%, 5\% and $10 \%$ levels, respectively. 
Table 3 reports the results of estimation of 5FM on ADRs from developed vs. emerging markets. We split the sample into developed market ADRs (Model I) and emerging market ADRs (Model 2) according to whether the ADR originates from a developed market or an emerging market. Results show that none of the five risk factors is significant at any conventional level in either market. However, the Alpha of 5FM is found to be positive and significant at I\% level (the coefficient is I46.I2 with an $t$-statistics of 2.75) in the emerging market ADRs, but insignificant in the developed market ADRs. Combined with the results in Table 2, the abnormal returns we documented in the previous section accrue mostly to the emerging market ADRs, and there is scant evidence that abnormal return exist in the developed market ADRs. In Model 3, we interact each of the five risk factors with an indicator variable, Developed, which equals one if the ADR originates from developed market, and zero otherwise. None of the interaction variables is significant at any conventional level, which implies none of the risk factors plays a significantly different role in developed market ADRs than in emerging market ADRs.

Table 4. Estimation of Carhart four-factor model in developed vs. emerging market ADRs

\begin{tabular}{|c|c|c|c|}
\hline & Developed market ADRs & Emerging market ADRs & All \\
\hline & $(\mathrm{I})$ & $(2)$ & (3) \\
\hline \multirow[t]{2}{*}{ Alpha } & II9.8I5 & $138.050^{\text {s.th }}$ & $\mathrm{I} 25.8 \mathrm{I} 6$ \\
\hline & $(\mathrm{I} .09)$ & $(2.76)$ & $(1.63)$ \\
\hline \multirow[t]{2}{*}{$R_{M t}-R_{f t}$} & 7.465 & $21.840^{*}$ & I6.833 \\
\hline & $(0.28)$ & $(\mathrm{I} .83)$ & $(0.53)$ \\
\hline \multirow[t]{2}{*}{$\left(R_{M t}-R_{f t}\right) \times$ Developed } & & & -9.732 \\
\hline & & & $(-0.26)$ \\
\hline \multirow[t]{2}{*}{$S M B$} & 46.873 & -7.052 & $-\mathrm{I} 6.4 \mathrm{I} 3$ \\
\hline & $(0.84)$ & $(-0.20)$ & $(-0.17)$ \\
\hline \multirow[t]{2}{*}{$S M B \times$ Developed } & & & 62.613 \\
\hline & & & $(0.59)$ \\
\hline \multirow[t]{2}{*}{$H M L$} & 68.027 & I5.406 & 28.828 \\
\hline & $(\mathrm{I} .30)$ & $(0.48)$ & $(0.33)$ \\
\hline \multirow[t]{2}{*}{$H M L \times$ Developed } & & & 39.061 \\
\hline & & & $(0.4 \mathrm{I})$ \\
\hline \multirow[t]{2}{*}{$W M L$} & 26.650 & 27.437 & 31.934 \\
\hline & $(0.70)$ & $(\mathrm{I} .2 \mathrm{I})$ & $(0.52)$ \\
\hline \multirow[t]{2}{*}{$W M L \times$ Developed } & & & -8.122 \\
\hline & & & $(-0.12)$ \\
\hline Observations & 69,738 & 33,929 & 103,667 \\
\hline$R^{2}$ & 0.008 & 0.029 & 0.009 \\
\hline Fixed effects & $\mathrm{F}, \mathrm{T}$ & $\mathrm{F}, \mathrm{T}$ & $\mathrm{F}, \mathrm{T}$ \\
\hline
\end{tabular}

Notes. The table reports the results of OLS estimation with fixed effects of Carhart four-factor model in developed vs. emerging market ADRs, respectively. The six developed markets (Model I) are Australia, France, Germany, Hong Kong, Japan and UK, and the five emerging markets (Model 2): Brazil, China, India, Russia and South Africa. The dependent variable is the excess return of ADRs between 2009 and 2019. Alpha of 4FM denotes the excessive return above the expected return due to market, size, value, momentum risk factors. $R_{M t}-R_{f t}$ is the excess return on the market portfolio (index). Developed is an indicator variable that equals one if the ADR represents shares of the company that locates in a developed market, and zero otherwise. $S M B$ is the size premium (small minus big). $H M L$ is the value premium (high minus low). WML is the premium on winners minus losers of past 12 months. F, $T$ denotes firm and time fixed effects, and the symbols and denote significance at the $1 \%, 5 \%$ and $10 \%$ levels, respectively.

In Table 4, we estimate 4FM on developed market ADRs (Model I) vs. emerging market ADRs (Model 2). Results show that the Alpha of 4FM and market risk premium $\left(R_{M t}-R_{f t}\right)$ are positive and significant in the emerging market ADRs, but none of risk factors is significant in the developed market ADRs. In Model 3, we interact each of the four risk factors with an indicator variable, Developed. None of the interaction variables is significant at any conventional level. Overall, the results in Table 4 are consistent with Table 3. 


\subsection{Estimation of 5FM and 4FM in ADRs by Origin-of-Market}

Now we break down ADRs by their origin-of-market and examined whether there exists difference among these markets. We estimate the 5FM in each individual market ADRs, results of the five emerging markets are reported in Panel A of Table 5, and results of the six developed markets in Panel B of Table 5.

Table 5. Estimation of Fama-French five-factor model in ADRs by origin-of-market

\begin{tabular}{|c|c|c|c|c|c|c|}
\hline \multicolumn{7}{|c|}{ Panel A: Emerging market ADRs } \\
\hline & Brazil & China & & India & Russia & South Africa \\
\hline & (I) & $(2)$ & & $(3)$ & $(4)$ & $(5)$ \\
\hline \multirow[t]{2}{*}{ Alpha } & 1.950 & $264.483^{2 \ldots x}$ & & -0.192 & 0.414 & -0.184 \\
\hline & $(0.78)$ & $(2.80)$ & & $(-0.10)$ & $(0.96)$ & $(-0.63)$ \\
\hline \multirow[t]{2}{*}{$R_{M t}-R_{f t}$} & $2.277^{2}$ & 30.660 & & 2.196 & $0.992^{2}$ & I.I64 \\
\hline & $(3.27)$ & (I.I5) & & $(4.25)$ & $(8.24)$ & (I4.23) \\
\hline \multirow[t]{2}{*}{$S M B$} & -1.364 & 3.887 & & $0.9 \mathrm{II}$ & -0.205 & -0.339 * \\
\hline & $(-0.8 \mathrm{I})$ & $(0.06)$ & & $(0.73)$ & $(-0.7 \mathrm{I})$ & $(-\mathrm{I} .7 \mathrm{I})$ \\
\hline \multirow[t]{2}{*}{$H M L$} & -1.117 & 57.173 & & -0.275 & 0.739 & $-0.786^{2}$ \\
\hline & $(-0.55)$ & $(0.72)$ & & $(-0.18)$ & $(2 . \mathrm{II})$ & $(-3.28)$ \\
\hline \multirow[t]{2}{*}{$R M W$} & -1.160 & 80.445 & & 3.179 & $-0.93 I^{\text {* }}$ & -0.520 \\
\hline & $(-0.4 \mathrm{I})$ & $(0.72)$ & & $(\mathrm{I} .54)$ & $(-1.92)$ & $(-1.55)$ \\
\hline \multirow[t]{2}{*}{ CMA } & 1.756 & -36.293 & & 1.299 & -0.267 & $1.565^{2}$ \\
\hline & $(0.7 \mathrm{I})$ & $(-0.37)$ & & $(0.74)$ & $(-0.64)$ & $(5.40)$ \\
\hline Observations & 6,792 & 18,953 & & $\mathrm{I}, 570$ & 2,003 & $4,6 \mathrm{II}$ \\
\hline$R^{2}$ & 0.029 & 0.029 & & 0.033 & 0.162 & 0.099 \\
\hline Fixed effects & $\mathrm{F}, \mathrm{T}$ & $\mathrm{F}, \mathrm{T}$ & & $\mathrm{F}, \mathrm{T}$ & $\mathrm{F}, \mathrm{T}$ & $\mathrm{F}, \mathrm{T}$ \\
\hline \multicolumn{7}{|c|}{ Panel B: Developed market ADRs } \\
\hline & Australia & France & Germany & Hong Kong & Japan & UK \\
\hline & $(\mathrm{I})$ & $(2)$ & (3) & $(4)$ & $(5)$ & $(6)$ \\
\hline \multirow[t]{2}{*}{ Alpha } & 15.764 & -0.099 & -0.082 & 0.194 & 244.358 & $\mathrm{I} 46.5 \mathrm{I} 8$ \\
\hline & $(\mathrm{I} .07)$ & $(-0.77)$ & $(-0.44)$ & $(\mathrm{I} . \mathrm{I} 8)$ & $(0.8 \mathrm{I})$ & $(0.9 \mathrm{I})$ \\
\hline \multirow[t]{2}{*}{$R_{M t}-R_{f t}$} & -2.015 & $1.080^{2}$ & $0.975^{2}$ & 0.787 & $-2.82 \mathrm{I}$ & 38.659 \\
\hline & $(-0.62)$ & $(31.90)$ & $(19.62)$ & $(21.80)$ & $(-0.03)$ & $(0.89)$ \\
\hline \multirow[t]{2}{*}{$S M B$} & 6.955 & 0.069 & 0.043 & 0.084 & $\mathrm{I} 65.2 \mathrm{IO}$ & -59.552 \\
\hline & $(0.99)$ & $(0.83)$ & $(0.34)$ & $(1.09)$ & $(\mathrm{I} .08)$ & $(-0.56)$ \\
\hline \multirow[t]{2}{*}{$H M L$} & $-\mathrm{I} .757$ & $0.306^{2}$ & 0.119 & 0.347 & I46.09I & -52.352 \\
\hline & $(-0.18)$ & $(2.67)$ & $(0.70)$ & $(3.23)$ & $(0.9 \mathrm{I})$ & $(-0.36)$ \\
\hline \multirow[t]{2}{*}{$R M W$} & 6.601 & 0.208 & 0.314 & $-0.358^{x}$ & I5.077 & -66.478 \\
\hline & $(0.57)$ & $(\mathrm{I} .4 \mathrm{I})$ & (I.44) & $(-2.8 \mathrm{I})$ & $(0.05)$ & $(-0.35)$ \\
\hline \multirow[t]{2}{*}{$C M A$} & 6.375 & -0.108 & 0.054 & -0.535 & -42.233 & 35.369 \\
\hline & $(0.58)$ & $(-0.76)$ & $(0.26)$ & $(-4.42)$ & $(-0.19)$ & $(0.19)$ \\
\hline Observations & 9,036 & 7,384 & 7,193 & 6,164 & $25,4 \mathrm{I} 6$ & $\mathrm{I} 4,545$ \\
\hline$R^{2}$ & 0.015 & 0.223 & 0.103 & 0.128 & 0.008 & $0.01 \mathrm{I}$ \\
\hline Fixed effects & $\mathrm{F}, \mathrm{T}$ & $\mathrm{F}, \mathrm{T}$ & $\mathrm{F}, \mathrm{T}$ & $\mathrm{F}, \mathrm{T}$ & $\mathrm{F}, \mathrm{T}$ & $\mathrm{F}, \mathrm{T}$ \\
\hline
\end{tabular}

Note. The table reports the results of OLS estimation with fixed effects of Fama-French five-factor model in each of the eleveninternational market ADRs. The dependent variable is the excess return of ADRs between 2009 and 2019. The eleven markets include five emerging markets (Panel A): Brazil, China, India, Russia and South Africa; and six developed markets (Panel B): Australia, France, Germany, Hong Kong, Japan and UK. Alpha of 5FM denotes the excessive return above the expected return 
due to market, size, value, profitability and investment risk factor. $R_{M t}-R_{f t}$ is the excess return on the market portfolio (index). $S M B$ is the size premium (small minus big). $H M L$ is the value premium (high minus low). $R M W$ is the robust-minusweak profitability factor computed by constructing the size and operating profitability-ranked benchmark portfolios. $C M A$ is the conservative-minus-aggressive investment factor computed by constructing size and INV-ranked benchmark portfolios. $F, T$ denotes firm and time fixed effects, and the symbols and denote significance at the $1 \%, 5 \%$ and $10 \%$ levels, respectively.

Among the five risk factors, market risk premium $\left(R_{M t}-R_{f t}\right)$ are found to be highly significant (less than $\left.1 \%\right)$ in the following seven markets: Brazil, the coefficient is 2.28 with a $t$-statistics of 3.27 ; India, the coefficient is 2.20 with a $t$ statistics of 4.25; Russia, the coefficient is 0.99 with a $t$-statistics of 8.24; South Africa, the coefficient is I.I6 with a $t$ statistics of 14.23; France, the coefficient is 1.08 with a $t$-statistics of 31.90; Germany, the coefficient is 0.975 with a $t$ statistics of 19.62; and Hong Kong, the coefficient is 0.79 with a $t$-statistics of 2I.80. Size premium $(S M B)$ is significant only in South Africa at 10\% level, but the coefficient is negative (-0.34). Value premium $(H M L)$ are found to be significantly positive in three market and significantly negative in one market: Russia, the coefficient is 0.74 with a $t$-statistics of $2 . I$ I South Africa, the coefficient is -0.79 with a $t$-statistics of -3.28 ; France, the coefficient is $0.3 \mathrm{I}$ with a $t$-statistics of 2.67 ; and Hong Kong, the coefficient is 0.35 with a $t$-statistics of 3.23. These results are consistent with multiple international evidence (Chan, Hamao, and Lakonishok (199I), Capaul, Rowley, and Sharpe (1993), Fama and French (1998) and Liew and Vassalou (2000)) which indicates that size and value effect is not spurious. Profitability premium $(R M W)$ is significantly negative in Russia (the coefficient is -0.93 with a $t$-statistics of 1.92 ), and Hong Kong (the coefficient is -0.36 with a $t$-statistics of -2.81 ). Finally, investment premium $(C M A)$ is significantly positive in South Africa (the coefficient is I.565 with a $t$-statistics of 5.40), and significantly negative in Hong Kong (the coefficient is -0.54 with a $t$-statistics of -4.42). The Alpha of 5FM is highly significant in China, which suggests the existence of substantial abnormal return in Chinese ADRs. Moreover, these results also imply that most of the abnormal return we document in Table 3 actually accrue to Chinese ADRs. Overall, 5FM works the best in Hong Kong with four out of five risk factors highly significant. Our results also show that substantial variations exist among these international ADRs when estimating the 5FM.

Table 6. Estimation of Carhart four-factor model in ADRs by origin-of-market

\begin{tabular}{|c|c|c|c|c|c|c|}
\hline \multicolumn{7}{|c|}{ Panel A: Emerging market ADRs } \\
\hline & Brazil & China & & India & Russia & South Africa \\
\hline & $(\mathrm{I})$ & $(2)$ & & $(3)$ & $(4)$ & (5) \\
\hline \multirow[t]{2}{*}{ Alpha } & $0.89 \mathrm{I}$ & $245.316^{\text {thx }}$ & & 1.655 & 0.079 & 0.087 \\
\hline & $(0.38)$ & $(2.72)$ & & $(0.97)$ & $(0.20)$ & $(0.32)$ \\
\hline \multirow[t]{2}{*}{$R_{M t}-R_{f t}$} & 2.227 & $39.182^{*}$ & & $1.682^{2}$ & 1.083 & $0.912^{2}$ \\
\hline & $(4.03)$ & $(\mathrm{I} .8 \mathrm{I})$ & & $(4.16)$ & (II.45) & (I3.96) \\
\hline \multirow[t]{2}{*}{$S M B$} & $-\mathrm{I} .452$ & -II.774 & & 0.567 & $-0.08 \mathrm{I}$ & -0.307 \\
\hline & $(-0.87)$ & $(-0.18)$ & & $(0.46)$ & $(-0.28)$ & $(-1.57)$ \\
\hline \multirow[t]{2}{*}{$H M L$} & 0.406 & 29.474 & & -0.926 & 0.919 & -0.038 \\
\hline & $(0.27)$ & $(0.53)$ & & $(-0.8 \mathrm{I})$ & $(3.5 \mathrm{I})$ & $(-0.22)$ \\
\hline \multirow[t]{2}{*}{$W M L$} & I.037 & 51.737 & & -0.265 & $-0.12 \mathrm{I}$ & $-0.232^{4}$ \\
\hline & (I.0I) & $(\mathrm{I} .22)$ & & $(-0.38)$ & $(-0.7 \mathrm{I})$ & $(-1.90)$ \\
\hline Observations & 6,792 & $\mathrm{I} 8,953$ & & 1,570 & 2,003 & $4,6 \mathrm{II}$ \\
\hline$R^{2}$ & 0.029 & 0.029 & & 0.032 & 0.160 & 0.094 \\
\hline Fixed effects & $\mathrm{F}, \mathrm{T}$ & $\mathrm{F}, \mathrm{T}$ & & $\mathrm{F}, \mathrm{T}$ & $\mathrm{F}, \mathrm{T}$ & $\mathrm{F}, \mathrm{T}$ \\
\hline \multicolumn{7}{|c|}{ Panel B: Developed market ADRs } \\
\hline & Australia & France & Germany & Hong Kong & Japan & $\mathrm{UK}$ \\
\hline & $(\mathrm{I})$ & $(2)$ & (3) & $(4)$ & $(5)$ & $(6)$ \\
\hline \multirow[t]{2}{*}{ Alpha } & I4.I52 & -0.023 & 0.010 & 0.025 & 273.307 & $\mathrm{I} 43.387$ \\
\hline & $(0.97)$ & $(-0.18)$ & $(0.05)$ & $(0.15)$ & $(0.94)$ & $(0.9 \mathrm{I})$ \\
\hline$R_{M t}-R_{f t}$ & -2.277 & $\mathrm{I} .08 \mathrm{I}$ & $0.966^{2}$ & $0.846^{2}$ & -0.737 & 32.179 \\
\hline (c) (i) (3) & & C 2020, CRIBF & IAFR & & & I \\
\hline
\end{tabular}




\begin{tabular}{|c|c|c|c|c|c|c|}
\hline & $(-0.74)$ & $(34.02)$ & $(20.67)$ & $(24.89)$ & $(-0.0 \mathrm{I})$ & $(0.79)$ \\
\hline \multirow[t]{2}{*}{$S M B$} & 4.082 & 0.035 & -0.013 & $0.256^{\text {柆 }}$ & $\mathrm{I} 4 \mathrm{I} .4 \mathrm{I} 3$ & $-5 \mathrm{I} .143$ \\
\hline & $(0.7 \mathrm{I})$ & $(0.45)$ & $(-0 . \mathrm{II})$ & $(4.03)$ & $(0.90)$ & $(-0.52)$ \\
\hline \multirow[t]{2}{*}{$H M L$} & -4.317 & 0.129 & -0.057 & $0.477^{2}$ & 177.410 & -11.619 \\
\hline & $(-0.6 \mathrm{I})$ & $(1.94)$ & $(-0.58)$ & $(6.15)$ & $(\mathrm{I} .30)$ & $(-0.14)$ \\
\hline \multirow[t]{2}{*}{$W M L$} & 6.413 & -0.037 & $-0.0 \mathrm{II}$ & $-0.102^{*}$ & $68.8 \mathrm{I} 4$ & -16.545 \\
\hline & $(\mathrm{I} .30)$ & $(-0.82)$ & $(-0.17)$ & $(-1.90)$ & $(0.67)$ & $(-0.29)$ \\
\hline Observations & 9,036 & 7,384 & 7,193 & 6,164 & $25,4 \mathrm{I} 6$ & $\mathrm{I} 4,545$ \\
\hline$R^{2}$ & 0.016 & 0.223 & 0.103 & 0.124 & 0.008 & $0.01 \mathrm{I}$ \\
\hline Fixed effects & $\mathrm{F}, \mathrm{T}$ & $\mathrm{F}, \mathrm{T}$ & $\mathrm{F}, \mathrm{T}$ & $\mathrm{F}, \mathrm{T}$ & $\mathrm{F}, \mathrm{T}$ & $\mathrm{F}, \mathrm{T}$ \\
\hline
\end{tabular}

Note. The table reports the results of OLS estimation with fixed effects of Carhart four-factor model in each of the eleveninternational market ADRs. The dependent variable is the excess return of ADRs between 2009 and 2019. The eleven markets include five emerging markets (Panel A): Brazil, China, India, Russia and South Africa; and six developed markets (Panel B): Australia, France, Germany, Hong Kong, Japan and UK. Alpha of 4FM denotes the excessive return above the expected return due to market, size, value, momentum risk factors. $R_{M t}-R_{f t}$ is the excess return on the market portfolio (index). $S M B$ is the size premium (small minus big). $H M L$ is the value premium (high minus low). $W M L$ is the premium on winners minus losers of past 12 months. F, $T$ denotes firm and time fixed effects, and the symbols and $10 \%$ levels, respectively.

In Table 6, we estimate the 4FM in each individual market ADRs, and report results of the five emerging markets in Panel A and results of the developed markets in Panel B. Market risk premium $\left(R_{M t}-R_{f t}\right)$ is found to be significant in eight markets: Brazil, China, India, Russia, South Africa, France, Germany and Hong Kong. The result that market risk premium is significant in all five emerging market $\mathrm{ADR}$ explains why we document a positive loading of market risk premium in emerging market ADRs in Table 4. Size premium (SMB) is highly significant (less than I\%) only in Hong Kong, the coefficient is 0.26 with a $t$-statistics of 4.03. Value premium $(H M L)$ is found to be significantly positive in three markets: Russia, France and Hong Kong. Momentum premium (WML) is significantly negative in two markets: South Africa and Hong Kong. The Alpha of 4FM is still highly significant in China, the coefficient is 245.32 with a $t$-statistics of 2.72 . Overall, 4FM works the best in Hong Kong with all four risk factors highly significant. Furthermore, there is no significant difference in the $R^{2}$ values between the 4FM (Table 6) and 5FM (Table 5), which implies both models may have a similar explanation power in the variations of returns of ADRs.

\section{Conclusions}

As interest in investing in foreign markets grows, ADRs have become one of the most convenient options to do so. The ADR market is expected to continue to grow as the world becomes more connected through trade and technology. Concurrently an understanding of international investment is needed to navigate the growing ADR markets. Our study examines whether the 4FM and the 5FM can explain variation in returns of I,230 ADRs originating from six developed markets including Australia, France, Germany, Hong Kong, Japan and UK and five emerging markets known as BRICS: Brazil, Russia, India, China and South Africa. Overall, we find that substantial variations exist among ADRs with respect to their origin-of-market. Both models show that most of the abnormal returns accrue to emerging markets ADRs, mainly Chinese ADRs. Among the risk factors, market risk premium is found to be the most prevalent in both emerging and developed markets with an exception of Chinese ADRs, in which market risk premium is insignificant in the 5FM and slightly significant in the 4FM. Although we find some differences in the presence of particular risk factors employed in the 4FM vs. 5FM among the eleven international markets ADRs, overall, there is no substantial evidence that the 5FM has stronger explanation power than the 4FM in capturing the risk and return patterns of international markets ADRs. For model fitness, both 4FM and 5FM show very low $R^{2}$ values, ranging from 0.008 to 0.223 . Even in markets like Hong Kong and South Africa in which most risk factors are significant, their $R^{2}$ values are still low, 0.128 and 0.099 respectively. This indicates that both models do not work well in international markets ADRs. Further research is needed to explore other risk factors that correlate to equity returns of ADRs.

\section{References}

Alhaj-Yaseen, Y. S., \& Ladd, D. (2019). Which sentiments do US investors follow when trading ADRs?. Journal of Economics and Finance, 43(3), 506-527.

Blau, B. M. (2017). Social trust and the liquidity of cross-listed securities. Journal of Business Research, 78, I55-17I.

Boubakri, N., Cosset, J. C., \& Samet, A. (2010). The choice of ADRs. Journal of Banking \& Finance, 34(9), 2077-2095. 
Capaul, C., Rowley, I., \& Sharpe, W. F. (1993). International value and growth stock returns. Financial Analysts Journal, 49 (I), 27-36.

Carhart, M. M. (1997). On persistence in mutual fund performance. The Journal of finance, 52(I), 57-82.

Chan, L. K., Hamao, Y., \& Lakonishok, J. (I99I). Fundamentals and stock returns in Japan. The journal of finance, $46(5)$, I739-I764.

Fama, E. F., \& French, K. R. (I992). The cross-section of expected stock returns. the Journal of Finance, 47(2), 427-465.

Fama, E. F., \& French, K. R. (I993). Common risk factors in the returns on stocks and bonds. Journal of Financial Economics, $33(1), 3-56$.

Fama, E. F., \& French, K. R. (1998). Value versus growth: The international evidence. The journal of finance, 53(6), I975I999.

Fama, E. F., \& French, K. R. (2015). A five-factor asset pricing model. Journal of financial economics, II6(I), I-22.

Foye, J. (2018). A comprehensive test of the Fama-French five-factor model in emerging markets. Emerging Markets Review, 37, 199-222.

Griffin, J. M. (2002). Are the Fama and French factors global or country specific?. The Review of Financial Studies, I5(3), 783-803.

Hail, L., \& Leuz, C. (2009). Cost of capital effects and changes in growth expectations around US cross-listings. Journal of financial economics, 93(3), 428-454.

Hong, H., Lim, T., \& Stein, J. C. (2000). Bad news travels slowly: Size, analyst coverage, and the profitability of momentum strategies. The Journal of Finance, 55(I), 265-295.

Hou, K., Xue, C., \& Zhang, L. (2015). Digesting anomalies: An investment approach. The Review of Financial Studies, 28(3), 650-705.

Jegadeesh, N. (1990). Evidence of predictable behavior of security returns. The Journal of finance, 45(3), 88I-898.

Jegadeesh, N., \& Titman, S. (I993). Returns to buying winners and selling losers: Implications for stock market efficiency. The Journal of finance, $48(\mathrm{I}), 65-9 \mathrm{I}$.

JPMorgan. (2006). ADR Reference Guide.

Kadiyala, P., \& Subrahmanyam, A. (2004). Divergence of US and Local Returns in the After-market for Equity Issuing ADRs. European Financial Management, IO(3), 389-4I I.

Karolyi, G. A. (2006). The world of cross-listings and cross-listings of the world: Challenging conventional wisdom. Review of Finance, IO(I), 99-I52.

Liew, J., \& Vassalou, M. (2000). Can book-to-market, size and momentum be risk factors that predict economic growth?. Journal of Financial Economics, 57(2), 22I-245.

Nijman, T., Swinkels, L., \& Verbeek, M. (2004). Do countries or industries explain momentum in Europe?. Journal of Empirical Finance, II(4), 46I-48I.

Notes

'North America does not have representing developed market sample because over $90 \%$ of the 28I9 Canadian firms are listed in US stock exchanges as ordinary listing (Morningstar). There is no representing developed markets sample available for Africa or South America, either.

ii Kenneth R. French's data library can be found at

https://mba.tuck.dartmouth.edu/pages/faculty/ken.french/data_library.html

\section{Copyrights}

Copyright for this article is retained by the author(s), with first publication rights granted to the journal. This is an open-access article distributed under the terms and conditions of the Creative Commons Attribution license (http://creativecommons.org/licenses/by/4.0/). 